\title{
慢性足関節不安定症の有無が片脚着地からの切り返し動作時の 足部機能に及ぼす影響
}

\author{
渡部貴 也 ${ }^{1 \dagger}$, 高林知 也 ${ }^{2,3}$, 久保雅義 ${ }^{2,3}$ \\ 1 新潟医療福祉大学大学院保健学専攻理学療法学分野 \\ 2 新潟医療福祉大学リハビリテーション学部理学療法学科 \\ 3 新潟医療福祉大学運動機能医科学研究所
}

\begin{abstract}
要旨：本研究は慢性足関節不安定症（CAI）の有無が片脚着地からの切り返し動作時の足部機能に及ぼす影響を明らかにする ことを目的とした，対象は健常成人男性 16 名の右下肢とした. Cumberland Ankle Instability Tool を用いて，対象者を健常群 8 名（年齢 $20.8 \pm 0.8$ 歳, 身長 $171.8 \pm 4.5 \mathrm{~cm}$, 体重 $61.0 \pm 5.4 \mathrm{~kg}$ ) と CAI 群 8 名（年齢 $20.1 \pm 0.8$ 歳, 身長 $173.8 \pm 7.1$ $\mathrm{cm}$, 体重 $62.3 \pm 8.2 \mathrm{~kg}$ ) に分類した. 課題は着地板が左もしくは右に $8 \mathrm{deg}$ 傾く場合と傾かない場合の 3 パターンで着地し てもらい，傾いた方向に 1 秒以内に素早く全力で跳ぶこととした．着地板の傾斜方向は対象者に知らされていなかった，CAI 群は健常群と同じパフォーマンスタイム（初期接地から足部離地までの時間）であったが, CAI 群は切り返し動作のミスの回 数が多く, 長腓骨筋反応時間の遲延がみられた。 今回のような動的課題では CAI 群は遂行すべき動作と意図する動作の不一 致が頻回に起こったことから，CAI 群は足部の傾きを正確に感知できないまま課題を遂行していると推察された.
\end{abstract}

キーワード : 慢性足関節不安定症, 片脚着地動作, パフォーマンス, 3 次元動作計測

\section{1. はじめに}

足関節内反捻挫は最も一般的なスポーツ障害であり，全 スポーツ障害の $15 \sim 30 \%$ を占める ${ }^{1,2}$. 足関節内反捻挫は 受傷時の重症度に関わらず, 疼痛, 固有感覚低下, 姿勢制 御機能低下, 病的な足関節の緩みなど, 足関節に慢性的な 後遺症が残存し, 頻回な再受傷を繰り返す. 慢性足関節不 安定症 (Chronic Ankle Instability：CAI) は, 慢性的に疼痛 や不安定感などの症状が残存し, 反復性の足関節捻挫に悩 まされている状態を表す疾患名として用いられている。 CAI には足関節弛緩性や関節の変性など構造面の問題により生 じる構造的不安定症 (Mechanical Instability：MI）と, 機能 面の問題により生じる機能的不安定症（Functional Instability：FI）があり, MI と FI が混在し足関節捻挫を繰り返すと 考えられている3). しかし, スポーツ現場においては, 足関 節捻挫は軽微なスポーツ外傷と捉えられ軽視されがちであ るため, 十分な治療を受けずに競技へ復帰してしまう選手 が多く, 捻挫は再発することが多い，それゆえ，足関節捻 挫は早期に治療することが大事である.

2019 年 4 月 25 日受付 2020 年 4 月 12 日受理

${ }^{\dagger}=950-3198$ 新潟県新潟市北区島見町 1398 番地

新潟医療福祉大学大学院修士課程保健学専攻理学療法学科

渡部 貴也

E-mail: hpm19012@nuhw.ac.jp
足関節内反捻挫の受傷機転として, 着地動作における内 反強制, ならびに方向転換動作が大多数を占めると報告さ れている ${ }^{4}$. 足関節捻挫は着地動作や方向転換動作で頻発し, バスケットボールに扔いては $45 \%$ が着地時に生じ, 半数が 非接触の損傷である. また， $30 \%$ が方向転換動作により生 じたと報告されている ${ }^{5}$. 着地からの切り返し動作はサッ カーやバスケットボールなど幅広いスポーツ競技で行われ ている動作であり，足関節内反が強制されやすい動作であ るため足関節捻挫を引き起こしやすい.

先行研究では, あらかじめどのような課題を行うかを対 象者が分かっている動作を行っている. そのため, 多くの 研究では受傷機転の動作に着目して研究を行なっている. 先行研究では静的評価として, レントゲン撮影による足関 節内反角度の増大 ${ }^{\text {() }}$ や片脚立位における重心動摇の増大 ${ }^{7}$ など多く報告されている. 足関節不安定性の動的評価とし ては, 反復横跳び切り返し動作を行い, 足関節捻挫群は内 反角度の増大と腓骨筋反応時間の遅延が見られた ${ }^{8)}$ と報告 されている. しかし, 足関節捻挫は不意に足部が傾くよう な意図していない状況での受傷である。 よって, 足部が不 意に傾くような動的な評価が重要だと考える. さらに, 長 腓骨筋と短腓骨筋は足関節の安定機構であり, 足関節内反 捻挫を防ぐ重要な筋であることが報告されている ${ }^{9)}$. した がって, 足部の動きのみだけではなく, 長腓骨筋の筋活動 を検証することも，足関節内反捻挫の予防に繋がると考え られる。 
本研究では, 足関節内反捻挫後の不安定性について, 足 関節捻挫の受傷機転である着地後に足部が不意に傾いた場 面に着目し, CAI の有無が足関節内反角度と足関節外反筋 である長腓骨筋の反応時間に及ぼす影響について検証する. これにより, 着地からの切り返し動作が多いスポーツ場面 において, CAI が足関節捻挫を繰り返す原因の検討に繋が ると考えられる。

\section{2. 方法}

\section{1 対象者}

対象は健常成人男性 16 名の右下肢とした。本研究はへル シンキ宣言に準拠し, 被験者に研究内容を書面および口頭 にて説明し同意を得た。また, 本研究は新潟医療福祉大学 倫理審査委員会の承認（承認番号 18185-190613）を得た上 で実施した . 対象者は, International Ankle Consortium によ るCAI の推奨基準 ${ }^{10)}$ を用いて健常群と CAI 群の 2 群に分 類した（表 1). CAI 群の包含基準は, 少なくともこれまで 2 回以上の右足関節内反捻挫の既往を有し, 足関節内反捻挫 の質問票である Cumberland Ankle Instability Tool（CAIT） を用いて CAIT スコアが 25 点以下であり ${ }^{11)}$, 足関節内反捻 挫以外の重大な整形外科疾患の既往がないこととした。健 常群の包含基準は, 右足関節内反捻挫の既往がない, もし くは 1 回のみであり, 足関節内反捻挫以外の重大な整形外 科疾患の既往がないこととした. 対象者には研究実施前に 十分な説明を行い，同意を得たうえで実施した。

\section{2 使用機器}

動作解析には, 赤外線カメラ 12 台を含む三次元動作解 析装置（VICON; Oxford Metrics 社製）および床反力計 (OR6-6-2000；AMTI 社）2 枚を使用した. 三次元動作解析 装置のサンプリング周波数は $250 \mathrm{~Hz}$, 床反力計によるサン プリング周波数は $1000 \mathrm{~Hz}$ とした. 赤外線反射マーカーは, 対象者の左右の上前腸骨棘, 上後腸骨棘, 大転子, 大腿骨 外側上顆, 大腿骨内側上顆, 大腿骨軸上の点, 外果, 内果, 下腿骨軸上の点, 第 1 中足骨頭, 第 5 中足骨頭, 踵骨隆起 の計 24 個に貼付した.

先行研究では, 足関節不安定性の動的評価として反復横 跳び切り返し動作や着地動作を行い, 長腓骨筋反応時間の 遅延がみられた ${ }^{8)}$ と報告されている. よって, 足関節捻挫 の受傷機転である動的な外乱に対する本研究でも足関節不 安定症の動的評価として長腓骨筋のみを被験筋とした。

計測前にアルコール綿で十分皮膚処理を行った後, 電極

表 1 各群における基礎情報

\begin{tabular}{ccccc}
\hline 群 $(\mathrm{n})$ & 年齢 $($ 歳) & 身長 $(\mathrm{cm})$ & 体重 $(\mathrm{kg})$ & CAITスコア(点) \\
\hline $\mathrm{CAI}$ 群 $(8)$ & $20.1 \pm 0.8$ & $173.8 \pm 7.1$ & $62.3 \pm 8.2$ & $23.9 \pm 2.2$ \\
健常群 $(8)$ & $20.8 \pm 0.8$ & $171.8 \pm 4.5$ & $61.0 \pm 5.4$ & $28.0 \pm 1.6$ \\
\hline
\end{tabular}

平均值 \pm 標準偏差
貼付位置は Aldo $^{12)}$ に従い, 腓骨頭より 3 横指遠位部に貼付 した。筋活動の計測には, 無線筋電図計（DELSYS Trigno； DELSYS 社）を用いた。 なお, サンプリング周波数は 1000 $\mathrm{Hz}$ とした.

\section{3 課題動作}

対象者は $20 \mathrm{~cm}$ の台上に右脚で立ち, 左脚は非荷重でリ ラックスし, 右脚で床反力計上に設置した着地板へ着地し てもらった。最初に降りてもらう位置を確認し, 着地する 時は視覚ではなく足部の感覚を意識してもらうため, 前方 を見ながら実施した. 対象者は, 足部が着地板に接地する までどの方向に傾くのか分からない. 傾く側にスポンジを 設置し, 足部が着地板に着いた瞬間にスポンジが潰れるこ とで, 着地板がスポンジ側に傾くように設定した. 対象者は, 着地板が傾いた方向に着地後 1 秒以内に出来るだけ早く跳 んでもらった．また，着地板が傾かなかった場合は前方へ 出来るだけ早く 1 秒以内に跳んでもらった. 着地板は, 左 右方向に傾く場合と傾かない場合の 3 つのパターンで実施 した（図 1，2）。また，傾く順番はランダムとした。

動作中は, 対象者の両手を腰に固定することとした. 非 着地脚が着地板に接地した場合, 大きく体幹が屈曲または 側屈した場合あるいは着地後 1 秒以内に跳べなかった場合 は失敗とした. 着地板が左右に傾く角度は $8 \mathrm{deg}$ と定義した. なお, 対象者には動作計測前に十分な練習時間を与えた後 に実施した. 各方向 3 回の成功施行を記録し, 成功施行が 得られるまで施行を追加して実施した。 また, 着地板が傾 いた方向と異なる方向へ跳んだ場合の回数も記録した.

\section{4 データ解析}

課題動作中に計測された反射マーカー位置に対し, 遮断 周波数 $6 \mathrm{~Hz}$ の Zero-lag Butterworth low-pass filter を実施し た ${ }^{13)}$. 解析ソフトは Body builder 3.6.4 (VICON ; Motion

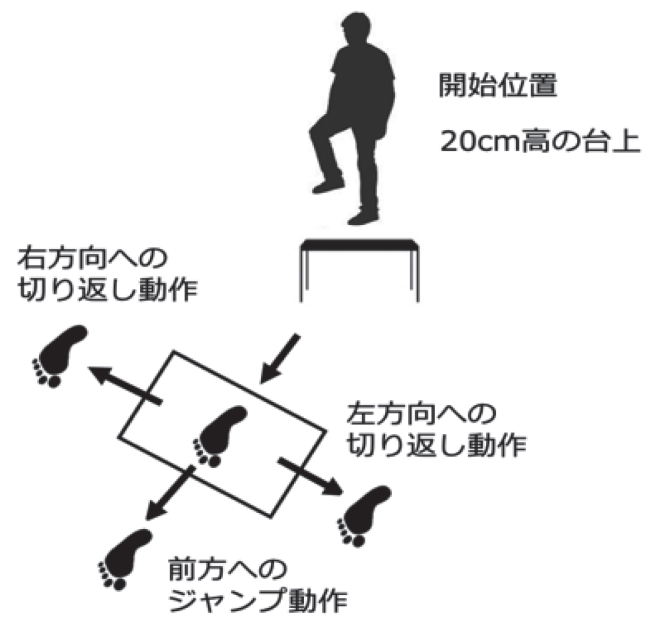

図 1 課題動作

対象者は $20 \mathrm{~cm}$ の台上から前方の床反力計上に設置した着地板へ着 地してもらい, 着地板が傾いた方向に着地後 1 秒以内に出来るだけ 早く跳んでもらった. 


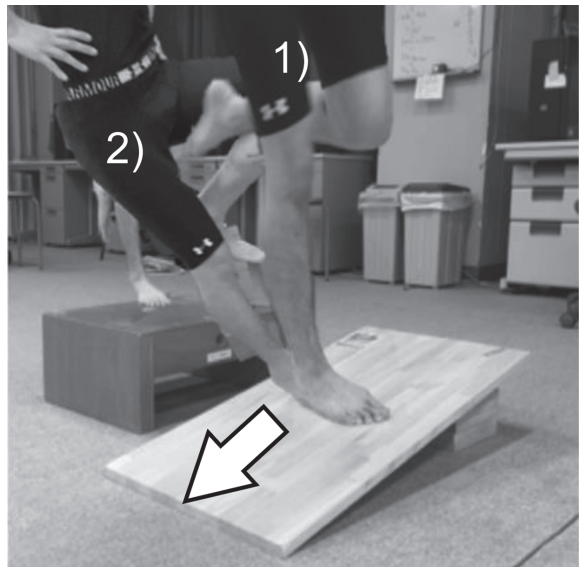

a）右方向への切り返し動作

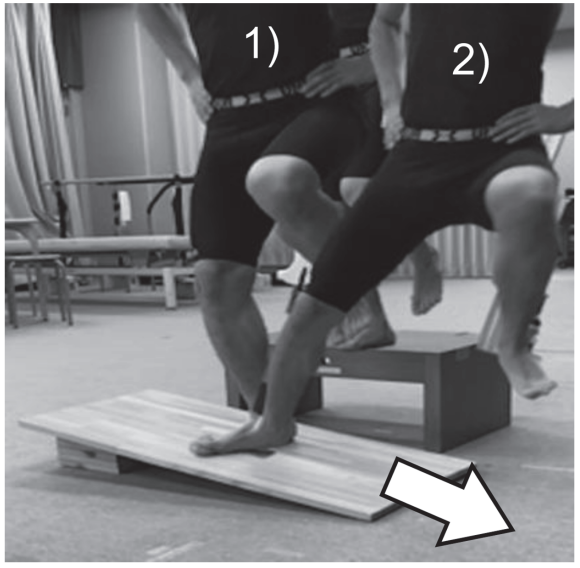

b）左方向への切り返し動作

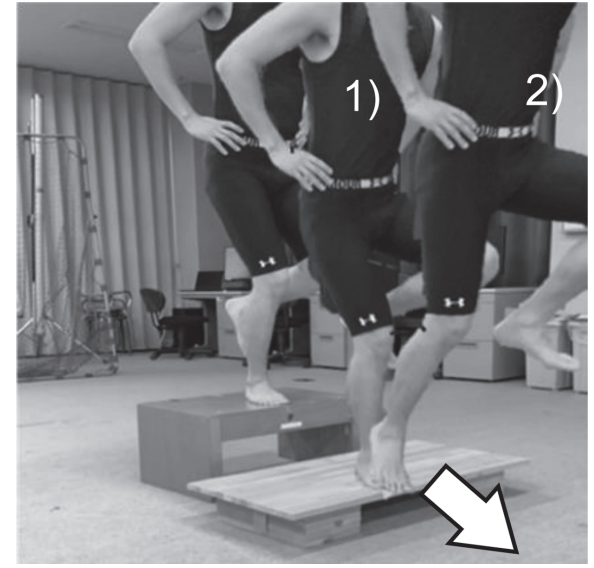

c）前方へのジャンプ動作

図 2 着地からの切り返し動作

1）初期接地時点, 2）足部離地時点と規定した.

system 社製）を用いた。空間座標系は床面を基準とし，X 軸は進行方向に対して右方向をプラス, $\mathrm{Y}$ 軸方向は進行方 向をプラス，Z 軸は天井方向をプラスとした。

本研究において, 局所座標系は下腿と足部を定義した. 下腿座標系は下腿内外果の中点を原点とした．原点と大腿 骨内外側中心を結ぶべクトルを Z 軸, 原点から外果を結ぶ 線を $\mathrm{X}$ 軸, 原点から前方に向かうべクトルを $\mathrm{Y}$ 軸とした. 足部座標系は踵骨隆起を原点とした. 原点から第 1 中足骨 頭と第 5 中足骨頭の中点に向かうべクトルを $\mathrm{Y}$ 軸, 上方に 向かうべクトルを $\mathrm{Z}$ 軸とした， Y 軸と $\mathrm{Z}$ 軸との外積によっ て得られる方向を $X$ 軸とした。本研究において, セグメン トは下腿と足部を定義した。下腿に対する足部の角度はオ イラー角 $(\mathrm{X}-\mathrm{Y}-\mathrm{Z})$ を用いて算出した。足関節の $\mathrm{Y}$ 軸に 対する運動方向は内反を（-), 外反を（+）とした（図 3 ).

解析区間は右脚の着地板への初期接地時から, 足部が床 面から離れる点（以下, 足部離地) までとした。初期接地 は垂直床反力が初めて $10 \mathrm{~N}$ を超えた瞬間として定義し, 一 方で離地は垂直床反力が初期接地後に初めて $10 \mathrm{~N}$ を下回っ た瞬間として定義した. 各データは初期接地を $0 \%$, 足部離
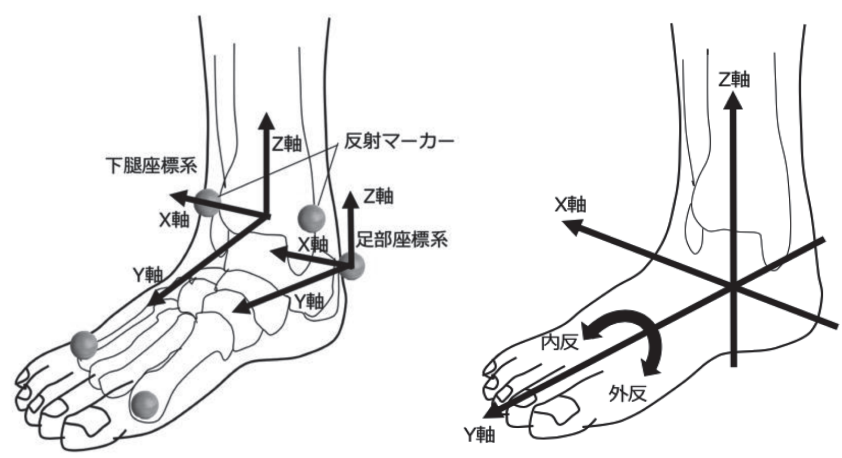

図 3 右下腿と足部の座標系

下腿に対する足部の角度はオイラー角 $(\mathrm{X}-\mathrm{Y}-\mathrm{Z})$ を用いて算出した. 足関節の $\mathrm{Y}$ 軸に対する運動方向は内反を $(-)$, 外反を $(+)$ とした.
地を $100 \%$ として時間正規化を行った. 本研究におけるデー 夕解析は, SCILAB-6.0.1 にてプログラミング処理した。筋 電図の解析には, 波形解析ソフトウェア (LabChart7 ; AD Instruments 社）を用いた。

長腓骨筋反応時間は, 初期接地後の筋電図波形の振幅が 静止立位時の筋活動の平均值の 3 倍を上回った時点を長腓 骨筋反応時間と規定した ${ }^{14)}$ (図 4). 各方向 3 回のデー夕の 長腓骨筋反応時間を求め, 3 回分の平均值を算出した.

足部離地時の切り返し角度は床反力データを基に計算し, 空間座標系の XZ 平面に射影した床反力ベクトルと空間座 標系 Z 軸とのなす角とした（図 5). CAI 群と健常群で足部 の不安定感の違いが傾斜した着地板からの左右方向への切 り返し動作時の跳び出す角度に違いがあると考え測定した. パフォーマンスタイムは解析区間である右脚の初期接地か ら足部離地までの時間と規定した。

\section{5 統計処理}

統計処理ソフトにはExcel 統計を用いた. CAI 群, 健常 群での足関節内反角度ピーク值, 長腓骨筋反応時間, パ フォーマンスタイム, 足部離地時の切り返し角度, 着地時 に足部接地面が傾いた方向と異なる方向へ跳んだ回数に対 して正規性の検定を行った。 2 群間で正規性のあるデー夕は 対応のない $\mathrm{t}$ 検定を, 正規性のないデータはマン・ホイット ニー検定を用いて比較検討した。 なお，有意水準は $5 \%$ と した.

\section{3. 結果}

着地時に着地板が傾いた方向とは異なる方向へ跳んだ回 数を表 2 に示す. 着地時に着地板が傾いた方向とは異なる 方向へ跳んだ回数では, 右方向に着地板が傾いた際にミス した回数で CAI 群に有意な増加が認められた $(p<0.05)$. 


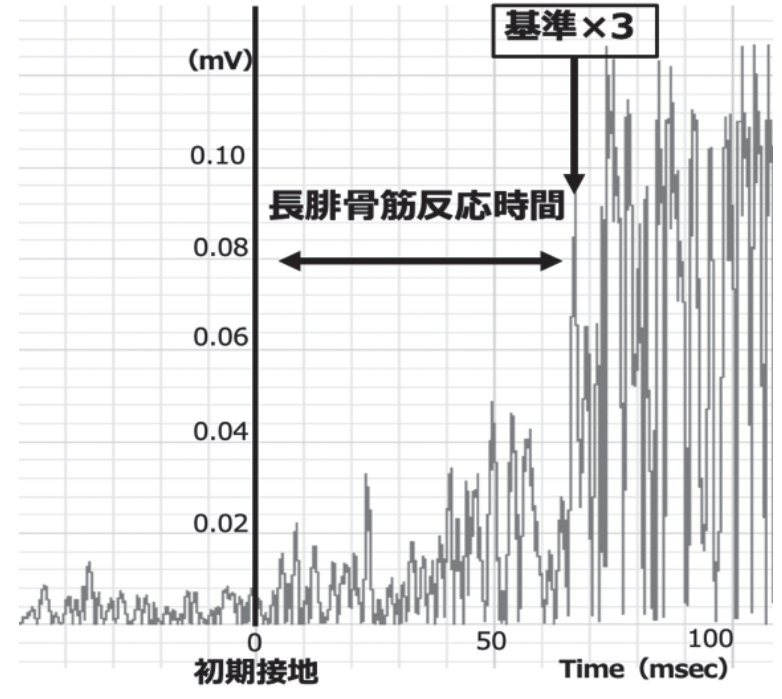

図 4 長腓骨筋反応時間

動作開始前の静止立位時間 3 秒間の筋電図波形の振幅の平均值を基 準とし, 初期接地後から基準の 3 倍を上回った時点を長腓骨筋反応 時間と規定した.

左方向に着地板が傾いた際や傾かなかった際のミスした回 数では, 2 群間で有意な差が認められなかった $(p \geqq 0.05)$.

足部離地時の垂直軸に対する床反力ベクトル $\mathrm{Z}$ 軸の傾き 角度を表 3 に示す. 足部離地時の垂直軸に対する床反力べ クトル Z 軸の傾き角度では, 左右方向での切り返し動作に おいて, 2 群間で有意な差が認められなかった $(p \geqq 0.05)$.

CAI 群と健常群の各方向のパフォーマンスタイムを図 6 に示す. 各方向のパフォーマンスタイムである右脚初期接 地から足部離地までの時間に，2 群間で有意な遅延は認めら れなかった $(p \geqq 0.05)$.

CAI 群と健常群の長腓骨筋反応時間を図 7 に示す。長腓 骨筋反応時間に関しては, 着地動作から左右方向への切り 返し動作において, CAI 群に有意な遅延が認められた $(p<$ 0.05). 一方, 着地動作からの前方へのジャンプ動作におい ては, 2 群間で有意な遅延は認められなかった $(p \geqq 0.05)$.

$\mathrm{CAI}$ 群と健常群の着地動作からの切り返し動作時の足

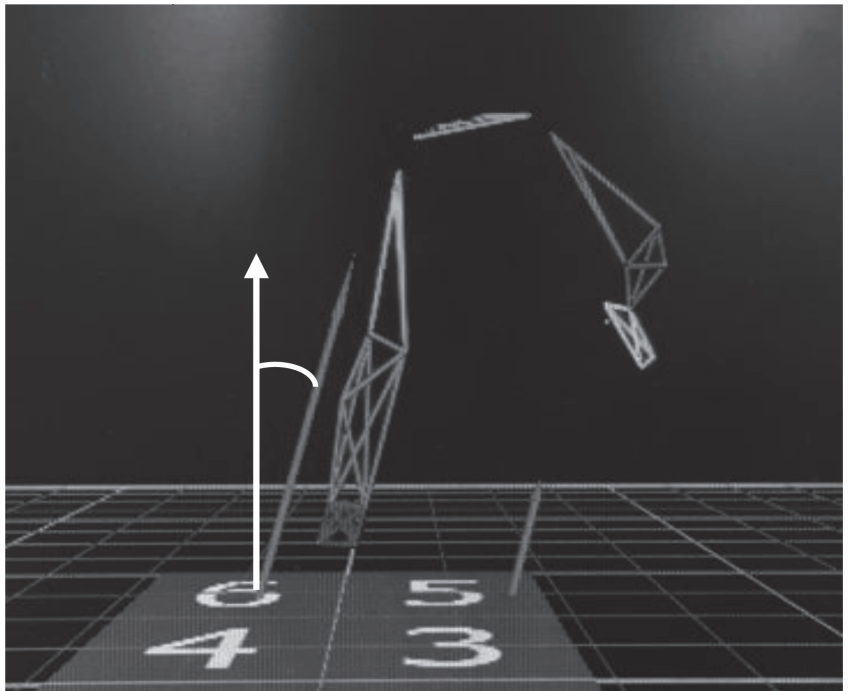

図 5 足部離地時の切り返し角度

空間座標系の XZ 平面に射影した床反力ベクトルと空間座標系 $\mathrm{Z}$ 軸 とのなす角とした。

表 2 着地時に着地板が傾いた方向と異なる方向へ跳んだ回数

\begin{tabular}{cccc}
\hline 傾く方向 & CAI 群 & 健常群 & $P$ 值 \\
\hline 右方向 & $4.5 \pm 1.6$ & $2.3 \pm 2.1$ & $0.03 *$ \\
左方向 & $1.6 \pm 1.1$ & $1.0 \pm 0.6$ & 0.19 \\
傾かない & $1.0 \pm 1.1$ & $1.3 \pm 1.8$ & 0.86 \\
\hline & & 平均值士槚淮㑦差 $* p<0.05$
\end{tabular}

表 3 足部離地時の切り返し角度（単位 : deg）

\begin{tabular}{cccc}
\hline 傾く方向 & $\mathrm{CAI}$ 群 & 健常群 & $P$ 值 \\
\hline 右方向への傾き & $20.3 \pm 3.5$ & $18.4 \pm 2.8$ & 0.31 \\
左方向への傾き & $18.1 \pm 3.9$ & $16.0 \pm 3.5$ & 0.14 \\
\hline & & & 平均值 \pm 標準偏差
\end{tabular}
a) 右方向への切り返し動作

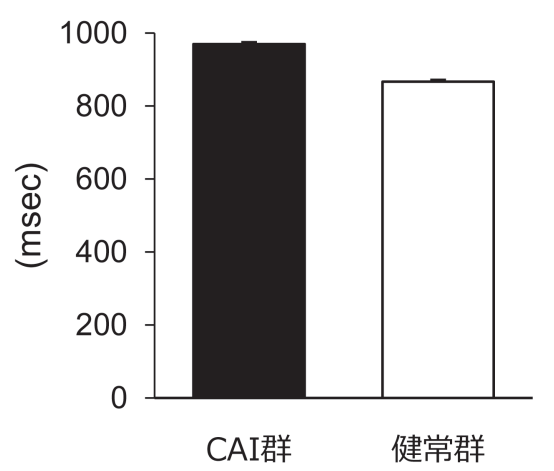

b) 左方向への切り返し動作

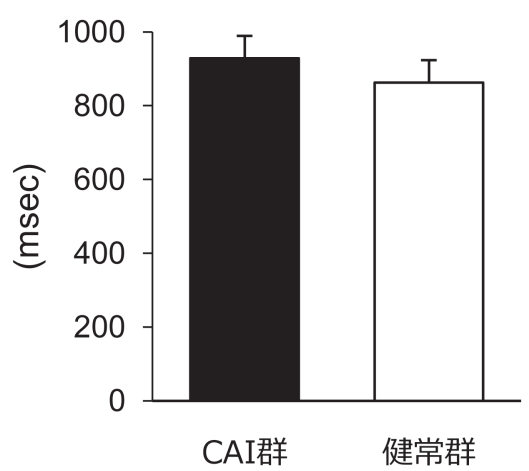

c) 前方へのジャンプ動作

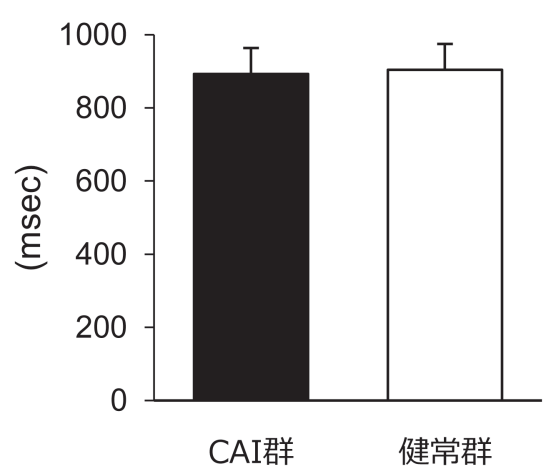

図 6 CAI 群と健常群におけるパフォーマンスタイムの比較 
関節内反 / 外反角度を図 8 に示す. 各データは初期接地を $0 \%$ ，足部離地を $100 \%$ とした。足関節内反角度のピーク 值を図 9 に示す. 着地動作から右方向への切り返し動作時 CAI 群は健常群と比較し，ピーク值（約 90\% 時点）に足関
節内反角度が有意に大きかった $(p<0.05)$. 一方, 初期接 地や着地から左方向への切り返し動作, 着地から前方への ジャンプ動作に関しては2群間で有意な差が認められなかっ た $(p \geqq 0.05)$. a) 右方向への切り返し動作

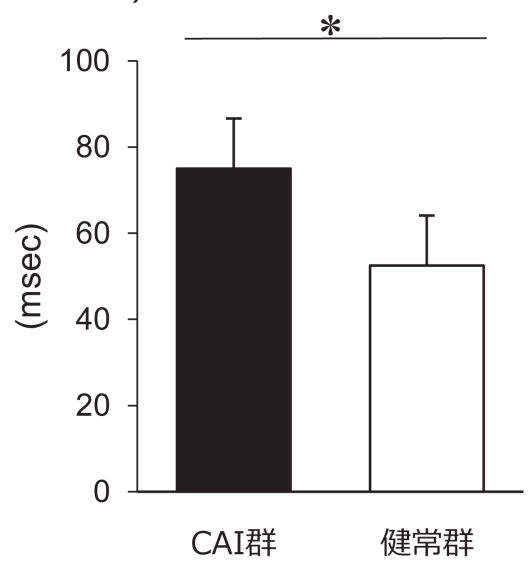

b) 左方向への切り返し動作

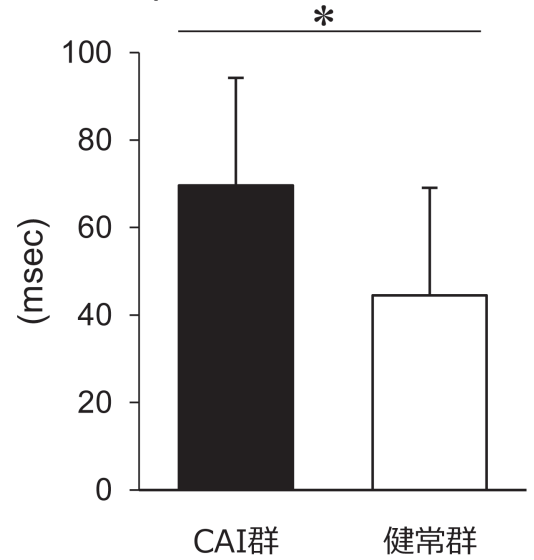

c) 前方へのジャンプ動作

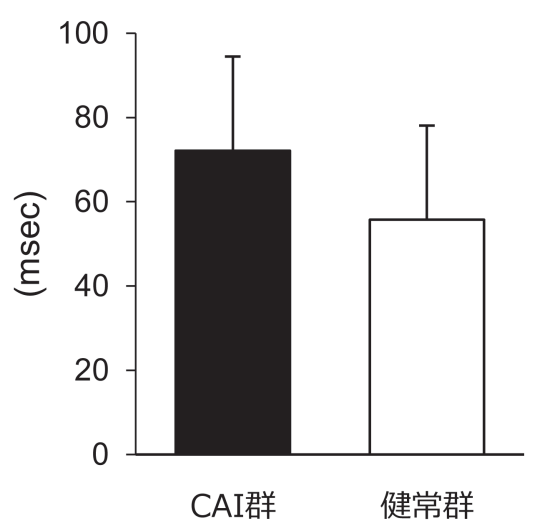

図 $7 \mathrm{CAI}$ 群と健常群の長腓骨筋反応時間 $\quad * p<0.05$

a) 右方向への切り返し動作

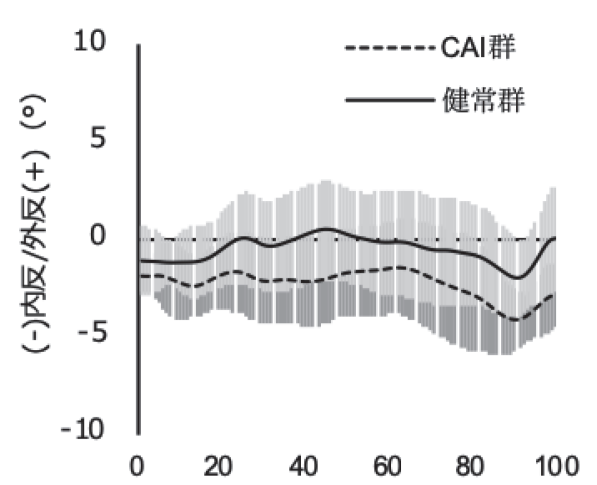

\%立脚期 b) 左方向への切り返し動作

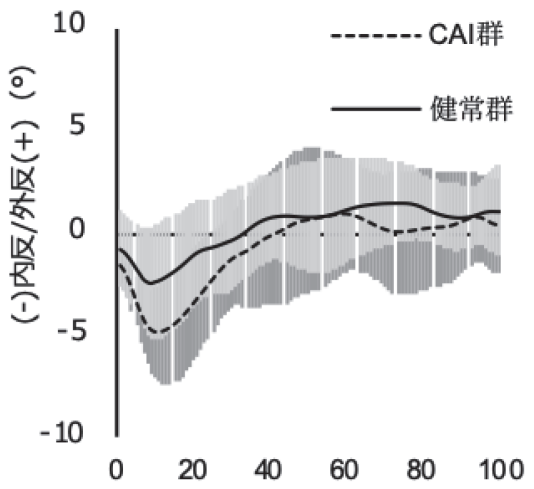

\%立脚期 c) 前方へのジャンプ動作

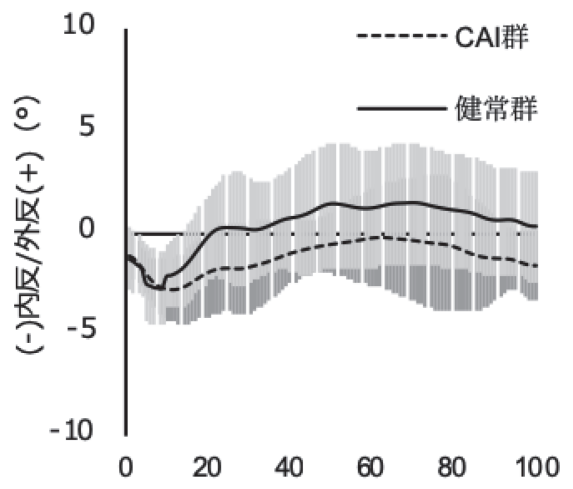

\%立脚期

図 8 片脚着地からの切り返し動作の初期接地から足部離地までの足関節内反 / 外反角度 各デー夕は初期接地を $0 \%$, 足部離地を $100 \%$ とした。

a) 右方向への切り返し動作

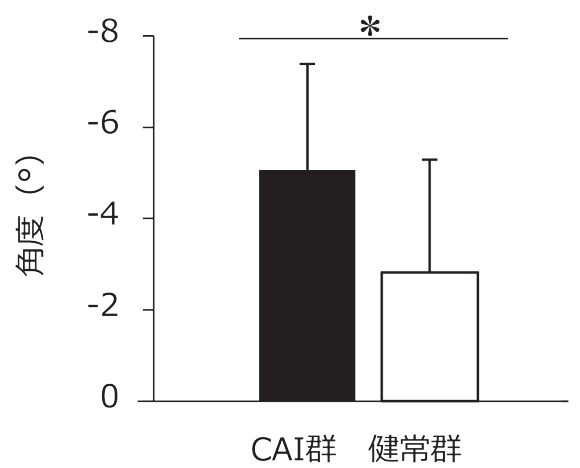

b) 左方向への切り返し動作

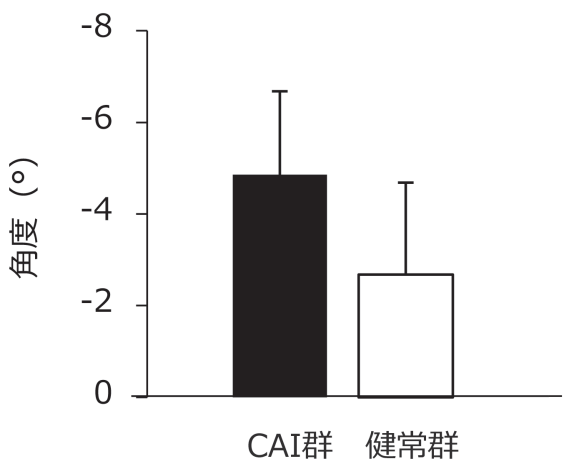

図 9 足関節内反角度のピーク值 $* p<0.05$ c) 前方へのジャンプ動作

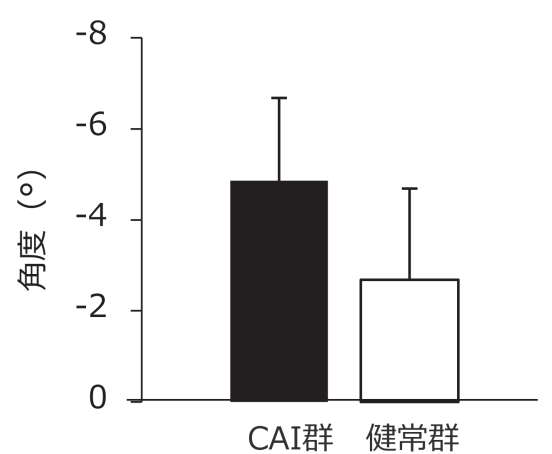




\section{4. 考察}

本研究では, 健常群と CAI 群で片脚着地から着地板が傾 いた方向に切り返し動作を行ってもらい, CAI の有無が足 部機能に及ぼす影響を検討した。先行研究では, CAI 症例 は反復横跳び切り返し動作や Giving-way 台を用いた研究で 足関節内反角度の増大や長腓骨筋反応時間の遅延が報告さ れているが ${ }^{8,15,16)}$, 受傷機転である着地動作後における内反 強制や切り返し動作を解析した研究はほとんどみられない. 受傷頻度が高いスポーツ種目であるバレーボールやバス ケットボールでは, 受傷原因の大多数はジャンプ着地時に 他選手の足の上に乗った際に不意に生じる足関節の内反で ある. 今回の研究では, 不意に足部の接地面が傾くという 点が実際の足関節内反捻挫の受傷場面を反映しており, 先 行研究と異なっている.

本研究結果から, 足部離地時の切り返し角度やパフォー マンスタイムを 2 群間で比較したが, 有意な差は認められ なかった。 よって, 着地から切り返し動作において成功施 行は, パフォーマンスとしては健常群と同じような結果を 出せることが明らかになった。

しかし, 着地時に着地板が傾いた方向と異なる方向へ跳 んだ回数を記録し, 着地板が右方向に傾いた際にミスした 回数が CAI 群は健常群と比較し有意に多かった. Lofvenberg らは急激な変位に対する足関節の固有覚反応の遅延は, 足関節の不安定性が原因である ${ }^{16)}$ と報告している. 先行研 究では, 静的評価として固有感覚の低下を報告されている が，本実験では実際のスポーツ場面に似た動的課題で足部 の傾きを正確に感知できていないことが明らかとなった. よって, CAI 群は実際の競技場面ではパフォーマンスを下 げないようにプレーすることでミスが増える可能性がある.

先行研究では, Giving-way 台を用いて長腓骨筋反応時間 の遅延を報告しており ${ }^{15,16)}$, 本実験でも着地板が左右どち らの方向に傾いた際にも, 長腓骨筋反応時間の遅延が認め られた. 先行研究と異なる点として, 本研究は足部接地面 が傾く方向を内反方向だけではなく，外反方向も実施した. 左右どちらの方向に傾いても長腓骨筋反応時間は遅延する 結果となった. Fremanは, メカノレセプター損傷による関 節固有感覚低下が, 慢性不安定症への移行へ繋がる ${ }^{15)}$ と述 べている.よって, CAI 群はメカノレセプター損傷による 関節固有感覚の低下，急激な変位に対する足関節の内反／ 外反方向の動きに対して長腓骨筋と前脛骨筋が同時収縮す ることで足関節を前額面上で安定させているため, 外反方 向に傾いた際にも長腓骨筋の反応時間の遅延がみられたの ではないかと考えられる。

足関節内反角度のピーク值は, 右方向への足部離地直前 に健常群と比較して CAI 群で有意な増加が認められた。足 関節内反捻挫は, 前距腓勒帯や踵腓勒帯などの足関節外側 に位置する組織の損傷が代表的であり，本実験では対象を 右下肢としたため, 右方向への足部離地直前に足関節外反
筋である長腓骨筋反応時間の遅延による影響から足関節内 反角度のピーク值の増大が生じたのではないかと考えられ る.

一方, 初期接地時の足関節内反角度はどの方向に傾いて も2 群間で有意な差が認められなかった。傾斜面に着地し た先行研究では, CAI 群と健常群の初期接地時の足関節内 反角度は有意差がないことを報告しており ${ }^{17)}$, 本研究結果 と一致している. CAI 群は不整地への初期接地時に, 足関 節捻挫を避ける保護戦略が生じているのではないかと考え られる。よって，不意に足部の接地面が傾いた場合に CAI 群は初期接地時ではなく右方向への切り返し動作の足部離 地直前に足関節内反角度のピーク值の増加が明らかとなっ た. スポーツ場面において着地からの方向転換動作は多い ため, CAI 群は着地からの切り返し動作時に, 足関節捻挫 の再発リスクに繋がる可能性がある.

本研究では, 片脚着地からの切り返し動作では, CAI 群 は健常群と同じパフォーマンスを続けることが可能である ことが示唆された.しかし, CAI 群は切り返し動作のミ スの回数が健常群と比較して多く, 短い時間で判断を要求 される今回のような動的課題では, 実際の足部の傾きを正 確に感知できないまま課題を遂行していることが明らかに なった.このような遂行すべき課題と, 意図する動作の不 一致が足関節内反捻挫の再損傷の発生原因の 1 つになるこ とが示唆された. よって, 今後は再損傷予防のために動的 条件で足関節固有受容器の検査と訓練が推奨されるかもし れない.

本研究の限界は, CAI 症例において観察された下肢関節 運動および筋活動に関する結果は, CAI を発症する前から, あるいはその後に存在していたかどうかについて結論付け ることは難しい. これらの問題を解決するためには, 今後 長期的な前向き研究を実施する必要がある.

\section{参考文献}

1) Wilkerson, L. A.: Ankle injuries in athletes, Primary Care, 19, 377-392, (1992).

2) Garrick, J. G. and Requa, R. K.: The epidemiology of foot and ankle injuries in sports, Clinics Sports. Clinics in Sports Medicine, 7(1), 29-36, (1998).

3) Hertel, J.: Functional anatomy, pathomechnics, and pathophysiology of lateral ankle insatability, Journal of Athletic Training, 37(4), 364-375, (2002).

4) Woods, C., Hawkins, R., Hulse, M. and Hodson, A.: The football association medical research programme: an audit of injuries in professional football: an analysis of ankle sprains, British Journal of Sports Medicine, 37, 233-238, (2003).

5) McKay,G., Goldie, P., Payne, W. and Oakes, B.: Risk injuries in basketball: injury rate and riskfactors, British 
Journal of Sports Medicine, 35(2), 103-108, (2001).

6) 田中亮: 足関節内反不安定性と足関節内反角度の測定 結果の関連性, 理学療法学, 27, 349, (2000).

7) 横山茂樹：足関節内反捻挫既往者における片脚立位時 の重心動摇, 理学療法学, 24, 539, (1997).

8）土山裕之, 谷田惣亮, 大西均, 尾下佳史：足関節内反 捻挫後における不安定性の検証 - 足関節内反角度と腓骨 筋反応時間の分析 -, 理学療法学, 34, 37-40, (2014).

9) 吉野浩一, 大野範夫, 千葉慎一, 宮城健次, 入谷誠: 関節病態運動学 14 足関節の病態運動学と理学療法, 理学療法, 東京, 24, 1475-1481, (2007).

10) Gribble, P. A., Delahunt, E., Bleakley, C. M., Caulfield, B., Docherty, C. L., Fong, D. T., Fourchet, F., Hertel, J., Hiller, C. E., Kaminski, T. W., McKeon, P. O., Refshauge, K. M., van der Wees, P., Vicenzino, W. and Wikstrom, E. A.: Selection criteria for patients with chronic ankle instability in controlled research: a position statement of the international ankle consortium, Journal of Athletic Training, 49(1), 121-127, (2014).

11) Wright, C. J., et al.: Recalibration with chronic ankle instability, Archives of Physical Medicine and Rehabilitation, 9(14), 00334-00337, (2014).

12) Edward, D. and Aldo, P.: Anatomic guide for the electromyographer: the limbs, 原著第2版. 栢森良二(訳), 西村書店, 新潟, 144-159, (1985).

13) 大見頼一, 尹成祚, 長妻香織, 川島達宏, 栗原智久,
小林朋美, 栗山節朗, 宮本謙司, 齋藤千津子, 加藤宗規： 膝前十字勒帯損傷予防プログラムのトレーニング効果 三次元動作解析による片脚着地動作と下肢筋力評価 -, 日本臨床スポーツ医学会誌, 20(1), (2012).

14) Hopkins, J.: Muscle activation following sudden ankle inversion during and walking, European Journal of Applied Physiology, 99(4), 371-378, (2007).

15) Freman, M.: Instability of foot after injuries to the lateral ligament of the ankle, Journal of Bone and Joint Surgery, 669, (1965).

16) Lofvenberg, R.: Prolonged reaction time in patients with chronic laterl instability of the ankle, American Journal of sports medicine, 23, 414, (1995).

17) Simpson, J. D., Stewart, E. M., Turner, A. J., Macias, D. M., Wilson, S. J., Chander, H. and Knight, A. C.: Neuromuscular control in individuals with chronic ankle instability: A comparison of unexpected and expected ankle inversion perturbations during a single leg droplanding, Human Movement Science, 64, 133-141, (2019).

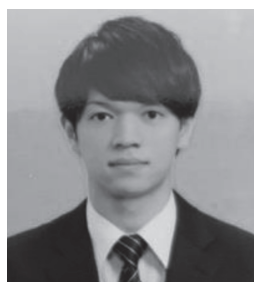

渡部貴也（わたべたかや） 2019 年新潟医療福祉大学医療技術学部理 学療法学科卒業. 現在, 新潟医療福祉大 学大学院保健学専攻理学療法学分野修士 課程在籍. 日本理学療法士協会.

(バイオメカニズム学会学生会員) 


\title{
Effect of the Chronic Ankle Instability on the Function of the Foot during Lateral Jump Immediately After Single Leg Landing
}

\author{
Takaya WATABE ${ }^{1 \dagger}$, Tomoya TAKABAYASHI ${ }^{2,3}$, Masayoshi KUBO ${ }^{2,3}$ \\ ${ }^{1}$ Field of Physical Therapy Master's Course, Graduate School, Niigata University of Health and Welfare \\ ${ }^{2}$ Department of Physical Therapy, Faculty of Rehabilitation, Niigata University of Health and Welfare \\ ${ }^{3}$ Institute for Human Movement and Medical Sciences, Niigata University of Health and Welfar
}

\begin{abstract}
The purpose of this study was to investigate the effect of the chronic ankle instability (CAI) on the function of the foot during lateral jump immediately after single leg landing. Using the Cumberland Ankle Instability Tool, 16 subjects were separated into the 8 healthy control group (age $=20.8 \pm 0.8$ years, height $=171.8 \pm 4.5 \mathrm{~cm}$, mass $=61.0 \pm 5.4 \mathrm{~kg}$ ) and 8 patients of CAI group (age $=20.1 \pm 0.8$ years, height $=173.8 \pm 7.1 \mathrm{~cm}$, mass $=62.3 \pm 8.2 \mathrm{~kg}$ ). The task was the landing with right leg on the board from the platform with $20 \mathrm{~cm}$ in height. The board was designed to tilt either in left or right by 8 degrees or 0 degrees, at the moment of landing. The subjects were instructed to perform the lateral jump within a second in the direction of the tilt or the forward jump if there was no tilt. There were no significant differences between the two groups in the performance time (from initial contact to toe off) of the jump and in the direction of the force vector applied to the board. However, CAI group significantly increased in the peak value of the ankle varus angle, delayed the reaction time of the peroneus longus muscle, and increased the number of mistakes in the jumping direction, when the board was tilted to the right. We concluded that, in the case of dynamic tasks that require the quick judgment of ankle inclination, the presence of CAI would result in the occurrence of disagreement between required and intended movements. For the purpose of re-injury prevention, examination, and training of proprioception of ankle joint in dynamic condition may be recommended.
\end{abstract}

Key Words: Chronic ankle instability, Single leg landing, Performance, Motion capture

\footnotetext{
Received Apr. 25, 2019 Accepted Apr. 12, 2020

${ }^{\dagger}$ Takaya WATABE

Field of Physical Therapy Master's Course, Graduate School,

Niigata University of Health and Welfare,

1398, Shimami-cho, Kita-ku, Niigata City, Niigata, 950-3198, Japan,

E-mail: hpm19012@nuhw.ac.jp
} 